Folia Phoniatrica

et Logopaedica
Folia Phoniatr Logop 2008;60:332-333

DOI: $10.1159 / 000173711$
Published online: November 20, 2008

\title{
Alexej Novak
}

\author{
December 1, 1930 to July 26, 2007
}

Prof. Novak died suddenly on 26th July 2007, aged 76 years. Born on the 1st of December 1930 in Dritec, Pardubice district (Czechoslovakia) as a son of a primary school teacher, Alexej Novak graduated from grammar school in Pardubice. Since 1950, he studied at the Faculty of Medicine, Charles University in Hradec Kralove at first, then in Pilsen since 1952. He took his degree in 1956.

Upon graduation, he worked as a secondary physician at the Department of Otorhinolaryngology in Usti nad Orlici for more than 3 years, and as a secondary physician with Prof. Dr. Seeman at the Phoniatrics Department of Faculty Hospital 2 in Prague since April 1960. In 19651968, he was assistant of phoniatrics at the Department of ORL of the Institute for Postgraduate Medical Education in Prague. Afterwards, he became the assistant of the Phoniatrics Department of the Faculty of General Medicine at Charles University (1968). In addition to his activities in the therapy and prevention of hearing, speech and voice disorders, he was actively engaged in research. In 1974, he defended the candidate thesis 'Voice Expression in Children with the Down Syndrome and in Children with Severe Oligophrenia without the Syndrome'. In 1980, he submitted his senior lecturer thesis 'Substitute Voice Mechanisms upon Total Laryngectomy'. He was appointed associate professor of otorhinolaryngology in 1984. He devoted himself to the field of phoniatrics and audiology in its full scope, as in 1988, he defended his doctorate thesis 'Phoniatric Aspect of Speech-Language Abilities in Children Aged 4 to 6 Years'. He was awarded the Dr.Sc. degree in 1989, and in 1990 he was promoted to professorship in otorhinolaryngology and phoniatrics.
In 1987-1997, Prof. Novak was the Head of the Phoniatrics Department of the First Medical Faculty of Charles University in Prague, and continued applying the most up-to-date scientific-technical knowledge in audiology and phoniatrics. He had merit in modern apparatus equipment and adaptation of outpatient departments and the bed ward of the department. Prof. Novak established the Auditory Centre at the Phoniatrics Department in 1992, oriented to the diagnostics of hearing disorders and auditory prosthetics. He developed the application of electrophysiological methods in terms of objective audiometry, elaborated a screening method of hearing impairment in children, and set up a children's speech intelligibility test. He devoted himself to voice professionals in the area of prevention and treatment of the speaking and singing voice. Prof. Novak had numerous friends among actors and singers.

Following the steps of his teachers, Prof. Miloslav Seeman, MD, and Ass. Prof. Eva Sedlackova, MD, he continued international cooperation with European (Union of European Phoniatricians, UEP) and world (International Association of Logopedics and Phoniatrics, IALP) organizations of phoniatricians and speech-language therapists. In 1972 and 1983, Prof. Novak acted as the secretary general of the UEP Congress; furthermore, he was a UEP General Secretariat member, and president of the Committee in 1991-1993. In 1986-1992, he was an IALP Committee member, and in 1989 president of the 21st World Congress of IALP held in Prague. He was an honorary member of the German Society for Phoniatrics and Pedaudiology, was awarded the medal of H. Gutzmann, and an honorary member of the Austrian Society for Phoniatrics and Logopedics.

\begin{tabular}{ll}
\hline KARGER & ( 2008 S. Karger AG, Basel \\
1021-7762/08/0606-0332\$24.50/0 \\
$\begin{array}{l}\text { E-Mail karger@karger.ch } \\
\text { www.karger.com }\end{array}$ & $\begin{array}{l}\text { Accessible online at: } \\
\text { www.karger.com/fpl }\end{array}$
\end{tabular}


In the Czech Republic, in 1987-1995, Prof. Novak was a member of the Czech Society for Otorhinolaryngology and Head and Neck Surgery Committee, and at the same time chairman of Phoniatrics and Pedaudiology of this society. In 1990-2000, he was a member of the board of editors of Otorhinolaryngology and Phoniatrics and Phoniatrica Latina.

Prof. Novak was very active in publishing: at present, he is and will remain the main author in phoniatrics and audiology in the Czech Republic - he published 11 monographs and more than 100 publications in Czech and foreign specialized journals. His publications cover all areas of speech, hearing and voice disorders in children and adults.

Even as a pensioner, he used to come to the Phoniatrics Department and take part actively in research in the field of the new Czech speech audiometry. His work was his lifelong liking, too, bringing benefit both to the patients and to his collaborators.

The First Medical Faculty of Charles University in Prague has lost a university teacher of outstanding pedagogical and human characteristics, who has brought up numerous highly qualified experts. Czech and Slovak medicine loses an outstanding researcher in Prof. Novak, who has achieved international acknowledgement due to his abundant work, and who has had a significant merit in building modern Czech and Slovak phoniatrics and audiology.

Thank you, dear professor. Honours to your memory.

Olga Dlouha, Ass. Prof., MD, PhD

The First Medical Faulty of Charles University and

General Faculty Hospital, Prague 